\title{
The Inscription of the Tavola da Este
}

\section{Pigozzo Gina}

Associazione Italiana Russisti, Milano, Italy

Email: gina.pigozzo@gmail.com

How to cite this paper: Gina, P. (2022). The Inscription of the Tavola da Este. Archaeological Discovery, 10, 1-34. https://doi.org/10.4236/ad.2022.101001

Received: October 3, 2021

Accepted: November 27, 2021

Published: November 30, 2021

Copyright $\odot 2022$ by author(s) and Scientific Research Publishing Inc. This work is licensed under the Creative Commons Attribution International License (CC BY 4.0).

http://creativecommons.org/licenses/by/4.0/

\begin{abstract}
This article is an interpretation, based on similarities with Slavic languages, of the Venetic inscription on the Tavola da Este (V-IV centuries B.C.), the longest Venetic inscription found so far. The result is a narrative text, of civic-religious nature. It confirms that: 1) the PaleoVeneti was a PaleoSlavic tribe, because their language was Slavic, enriched by the Greek; 2) the existence of narrative capabilities among the PaleoVeneti, always denied by historians. The only precedent translation of this inscription is from Ambrozič \& Tomezzoli (2003).
\end{abstract}

\section{Keywords}

Tavola da Este, Venetic, PaleoVeneti, PaleoSlavs, Veneti

\section{Introduction}

Observing and trying to read the so-called Tavola da Este fascinate proto-historical scholars, and are a puzzle for scholars of the Paleovenetic language. One can fantasize about how and where this inscribed bronze sheet was originally installed, in order to be read, with that concentric shape of the text, out of the ordinary and perhaps of symbolic value. Was it read aloud by some expert in writing and rituals? Or was it perhaps a votive object?

And who was the engraver? A writing master from Este (Athesis, from the Paleovenetic Vadis-Adige) or a Paduan master (from Pada, Paleovenetic name of Padua)? Whatever the answers, we owe them to Stefano Buson who, after the discovery in 1979 of this find, which remained for years in the deposit of the Este National Museum recovered, restored and studied it from a technological point of view.

\section{Some Coordinates to Historically Frame the Tavola da Este}

Based on paleographic analysis, also carried out thanks to X-rays, and a chemical-physical analysis of the European Restoration Center in Florence, this in- 
scribed bronze sheet dates back to the end of the fifth or the beginning of the fourth century BC. Therefore it is totally unrelated to the Romanization of north-eastern Italy, which began in the III century BC. It is a fruit of the Iron Age and the Hallstatt civilization (VIII-V century BC), that is, the second phase of the Paleovenetic civilization.

This civilization developed between the Adriatic Sea and the Baltic Sea, in the sense of latitude and between the Black Sea and Lake Constance and Lusatia ${ }^{1}$, in the sense of longitude. Therefore it is also called the "Lusatian civilization".

Its first phase belongs to the Bronze Age or culture of Unětice (about 2000-1500 BC), it is still characterized by the practice of burial of the dead, then gradually replaced by that of cremation (2), which first manifested itself between the Balkan mountains and the Elbe river (Labe, for the Slavs). The second phase belongs to the Iron Age (from $1500 \mathrm{BC}$ until Romanization) and is characterized by the practice of cremation, definitive and generalized starting from $1300 \mathrm{BC}$. up to Christianity. Therefore it is also called the "Urnfield civilization".

Both in the first (Bronze Age) and in the second phase (Iron Age) obviously the production and use of metals, activities of Balkan origin, developed. The original land of iron production was Anatolia. Bronze production continued at full speed during the Iron Age, also because the melting point of bronze (alloy of copper and tin) offers the advantage of being lower than that of steel (alloy of iron and carbon). The "Tavola da Este" is, in fact, an example of a bronze object dating back to the Iron Age.

But iron spread anyway, thanks to improved smelting techniques and thanks to the fact that this metal was present in local rocks (e.g. in the Fursil mines, Dolomites), which did not oblige the need to import other components, as was the case with tin, necessary in the production of bronze. Moreover, the production of copper continued at full speed, at the same time as that of bronze and iron, although it had been the most ancient in metallurgy, starting from the fourth millennium BC. This is attested, for example, in the "Acqua Fredda" archaeological site at the Redebus pass (eastern Trentino), where the ovens dug into the earth and used to melt copper in the 12th-11th centuries BC, in the middle of the Bronze Age, are preserved.

Here is a minimal inventory of the main settlements of the Paleovenetic civilization in the first phase (Bronze Age civilization): in addition to Únětice (Czechia), Biskupin (Poland), Vráble (Slovakia), Sotciastel (in South Tyrol) and Tyrol, the Euganean Hills, Este, Vicenza, Oderzo, called Terg in Paleovenetic and Opitergium in Latin (in the Treviso province), Frattesina in Polesine and Adria ${ }^{2}$ ${ }^{1}$ Lusatia extends between northern Czechia, southwestern Poland and eastern Germany (Saxony and Brandenburg). In Lusatian it is called Łužyca, in Polish Łužyce, in Czech Lužice, a Slavic name which means "very wet ground, swamp". The Germans call it Lausitz.

${ }^{2}$ Adria became Etruscan in the sixth century BC, after the demographic and productive downsizing of the Po Delta, and then it will become a Sicilian colony. The Etruscans, having crossed the Apennines, reached the coast of southern Veneto across the Po Valley. They called this settlement "Adria", making it the easternmost Etruscan city. Please refer to the Guide of the National Archaeological Museum of Adria (available in internet) for the relations between Veneti and Etruscans, and between Veneti and Greeks. 
(see Note 3) (both in the Rovigo province), Istrian castles such as Nezakcij (Croatia). Among the first European members of the Bronze Age, the Celtic Golasecca (Varese province) and Majkop (Northern Caucasus) belonging to the civilization of the funeral kurgàn tumuli).

Some of the main sites of the second phase (Iron and Urn Fields civilization) are, in addition to Halstatt (Austria) which gave its name to this civilization, Middle Friuli, South Tyrol (Fritzens-Sanzeno and Luco-Meluno), the Venetian Pre-Alps between the Garda Lake and the Brenta River, Padua, Altino (in the Venice province), the Belluno area (one of the first suppliers of iron), La Tène (Western Switzerland), Most na Soči (Slovenija), Picugi (pronounced Pizzùghi), near Poreč (Croatia) and various Friulan and Venetian Castellieri. The Villanovan civilization, attested in central Italy, greatly contributed to introducing the Iron civilization in the Italian peninsula. These settlements are mentioned here at the time of their maximum development, but they existed much earlier.

\section{The Tavola da Este}

The so-called Tavola da Este" (Figure 1), only partially legible, is actually the part cut out from a larger sheet, we do not know how much larger, presumably quadrangular. The first hypothesis is that, to exhibit texts or tell stories of public interest, the Paleoveneti used very thin inscribed bronze sheets, like this one, perhaps fixed on a plane, to make them legible. The second hypothesis is that the Tavola had a purely religious votive function.

This cut-out piece measures $23.5 \mathrm{~cm} \times 29 \mathrm{~cm}$, has a $0.6 \mathrm{~mm}$ thick sheet. Someone thought, at first, it was a greave. But it does not have the form; moreover it is

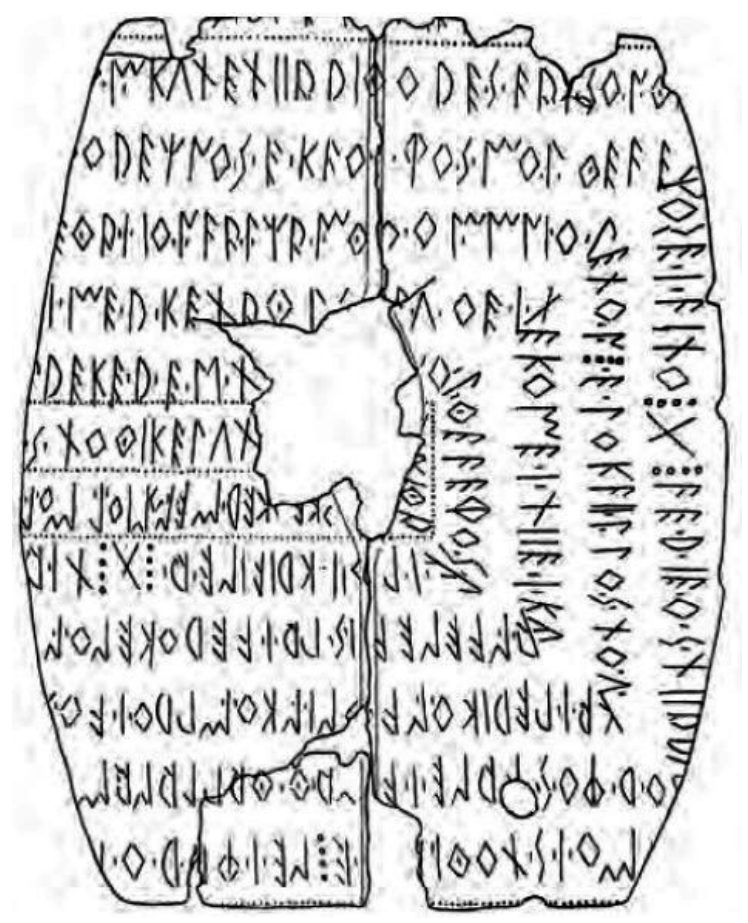

Figure 1. Text engraved in the Tavola da Este (Ambrozič \& Tomezzoli, 2003). 
too small and thin to be a greaves (which protected the warrior's leg from the ankle to the knee included). This cut piece was destined for another reuse. The restorer Stefano Buson recognizes in this piece of cut inscribed foil a votive shield with a longitudinal rib and an embossed central umbo, similar to other smaller ones found in the area. And he has reconstructed a similar one, which is exhibited at the Este Museum.

The Tavola was found by chance, underground in Este, during excavation works, rolled up, in filler earth in a Roman excavation, flattened, very degraded, with the inscription inside. Had this votive shield been hidden for later retrieval, or had it been rolled up and put away forever, like a curious antique piece? Certainly the inscription did not matter to whom who cut it, cutting words and phrases at the edges, so as to make the text fragmentary, therefore incomplete. And when, and by whom, was it cut? In Roman times, when was that written text no longer interesting? From invaders? For the image, please refer to table $\mathrm{n}$. 27 and on p. 196 of AA.VV. (2001-2002) and in AA.VV. (2013a, 2013b).

\section{Observations on Writing, Language and Style of the Tavola da Este}

In the Tavola, from the writing point of view, we note with the naked eye:

1) that the text was engraved concentrically on six quadrangular lines, rotating around a central pivot;

2) that of all the Paleo-Venetic inscriptions, this example is one of the most regular in height and width of the engraved letters, and the most regular of all, if we consider the first four lines, starting from the external one. Already on the fourth line some letters begin to be irregular; the letters of the central line, then, tend to be more compressed, as if the space was about to end. This suggests that this is the sixth line, that is, the last to read.

As for 1), examples of Palaeo-Venetic writing at right angles, which follows the frame of a table, are preserved in the Pieve di Cadore Museum, coming from the site of Làgole, and dedicated to the divinity Trumuziàt and to the Padua Civic Museums. The first examples are metallic, the Paduan ones of stone. But, apart from these cases, the writing of the ancient Veneti was boustrophedic, mostly left-handed (from right to left), and the opposite in the next line, reproducing the movement of the plow. Paleo-Venetic texts that occupied more than two lines have not been found, other than this. A concentric Venetic inscription, and of such a long text, is truly an exceptional find, unless other similar ones have been lost or destroyed, in the various historical-political events that involved the territory, or due to floods and cataclysms.

As for 2), the accurate and regular execution of the writing, in this case right-handed (from left to right), the first impression is that the work was entrusted to an expert in the trade, since it was an important text. And, in the Paleo-Venetic culture, the importance of the text stemmed either from its public nature, involving the community, or from its religious nature, a personal ma- 
nifestation of devotion to the deities. Certainly, the type of writing material also influences the regularity of the writing: it is more easily to engrave on a smooth metal sheet, rather than on a stone or a pebble, or on the handles of buckets and ladles, or on a bone. Other examples of regular paleo-Venetic writing are, for example, the engravings on the bronze writing styli, given their short, narrow and elongated shape which obliged to draw letters of the same size. In general, it is noted that the Paleo-Venetic inscriptions are much more irregular, moving away from the territory of Este and Padua, for example those of Vicenza and Cadore. Either they are more archaic, or those settlements did not have real writing schools, although a fragment of a writing tablet for didactic use is preserved in the Archaeological Museum of Vicenza.

As for the alphabet, the presence in the Tavola of the two distinct dental d, $t$ : " $\odot$ " (corresponding to T) and "X" (corresponding to D), and of the hooked "P", characteristics of the Paduan script of the 5th century BC, suggest, as Marinetti (1993) observed, the writing school of Padua (Figure 2). It is not excluded that the engraver, Atestin, had studied writing in Padua, or that he had moved from Padua to Este. The hypothesis supported by several parties that the engraving came from Padua and ended up in Este, for the most varied reasons, is not entirely convincing. Lejeune (1974) points out that no texts dating back to the "archaïque" period come from Padua, meaning by "archaic" the period from 550 to $475 \mathrm{BC}$. The oldest paleovenetic inscription, from the sixth century BC, comes from the territory of Este, precisely from "scolo di Lozzo"3. Este is older than

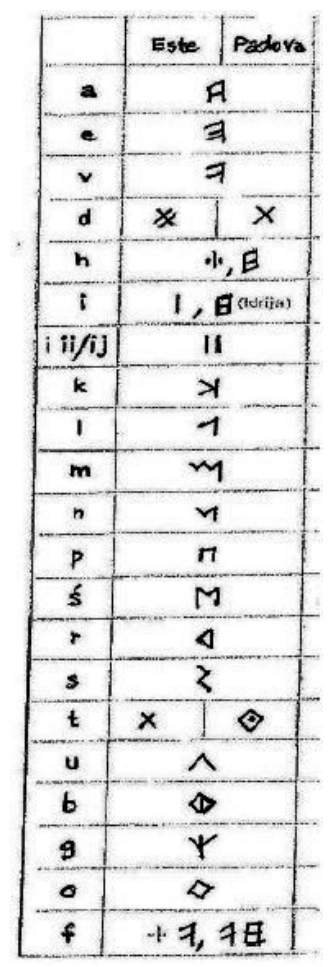

Figure 2. Paleovenetic alphabet.

\footnotetext{
3"low" water collector west of the Euganean Hills.
} 
Padua. In addition, the existence of an Atestin writing school is evidenced by the bronze writing tablets, still preserved in the National Atestin Museum.

As from the content, the inscription is clearly distinguished from all the others of the same period and the same region, definitely for the length (the other texts do not exceed ten words) and, at first glance, also for the lexicon, the discussion of the theme and the general tone. But this is a judgment that only an analytical understanding/translating of the inscription can justify.

The Paleoveneti have not left a literature. Not being able, therefore, to speak of their "literary genres", it is possible to say that the Paleo-Venetic inscriptions found are in most cases dedicatory, addressed to the dead or to divinities (for example Šainatei Trimuziatei, that is "to the shining Trimuziat"; Ego Neirkai Iuvantnai, that is "I offer it to the deceased Iuvantna"). They reveal a sacral, i.e. primordial, conception of writing, typical of the most ancient civilizations: the writing has to be used for religious, or solemn, or perennial messages, not for daily or biographical information. In addition to the dedicatory ones, the other inscriptions are aphorisms and reflections; some serve as a useful indication of the place. Eg:

Ego kantài tàjnon tàj, Slavic expression that means "Keep your own situlae in secret", that is "Be reserved, do not show your offerings to the deities, nor your mourning" (the situlae, or buckets, served as votive offerings, as cinerary urns, as well as to collect and pour the thermal waters and wine) (Pääbo, 2011).

Ti valej, Bellen ei, which means "You (pebble) fall down, while the god of light Bellen stands (he is immutable, perpetual)" (engraved on a pebble from Padua).

TE in italics corresponds to e, which means "here it is" (here it lies), with reference to the burial of a deceased (on pebble, Museum in Oderzo).

Vremja ist na which means "Time is gone" (the span of a lifetime is over) (on a small pot-bellied vase called olletta, Este National Museum).

Do stizei mesdei flies i kos nis ka rikoi which means "Along the path of half, oxen and sickle and, below, to the mines" (on the paths to be taken near Mount Pore; from stele, Museum of Bolzano) Pigozzo Bernardi (2020) Pigozzo Bernardi (2021).

So, as scholars agree, it is the uniqueness that distinguishes this Atestin find. But communicative themes and objectives cannot be defined without having understood the text, without having first translated it! What authorizes to define it, as some do, a "juridical" text, "on the borders" or even "a treaty between Padua and Este" a priori, without having understood even a word of it? Indeed, we still have to find out if the reading of the text should start from the innermost line or from the outermost one. For now we can say that it is a unique text from the point of view of the writing technique, of the dimensions, of the general style, of the way in which it is supposed to be presented to the public: not planted on the ground like a stela, nor hung on a wall, or to the branches of trees, according to paleo-Venetic customs. Perhaps it was fixed on a wooden surface, in order to be able to walk around it and read it looking at it from above, given the concentric lines. Unless it was a votive object. 
The Tavola was fully transcribed, and transliterated into the Latin alphabet, for the first time by Marinetti (1993), professor of Glottology at the University of Venice.

\section{Understanding the Tavola da Este}

\subsection{Preliminary Reflection}

In an attempt to understand a text in an unknown Paleo-Venetic language, first of all, a comparison is made with other languages already known (in the case of a text of the 5th century BC, with Sanskrit, Greek and Etruscan, Celtic languages, Germanic languages and Paleo-Slavian languages). Through this comparison, an attempt is made to identify in the text itself some significant keyword already known in other languages (a toponym, an idronym, a name, an ethnic group, a divinity, a word or an etymology that we may still use today). It will need to begin to separate the words, which do not appear divided from each other in the Paleo-Venetic texts. Keeping in mind that the dots engraved between the various letters in the Paleo-Venetic texts, although Lejeune (1974) called them "ponctuation syllabique", that is, points that separate syllables, did not serve at all to distinguish one syllable from another (at least, as we divide them). They were dictated by other criteria, still not entirely clear. One of the first hypotheses in this regard is that of Federico Cordenons (1894): in his opinion the dots, replacing vowels, acted as abbreviations. Aldo Prosdocimi (AA.VV. 2001-2002) saw, instead, in the dots, one of the teaching functions of writing. This is not the specific place to solve the problem, but whatever explanation to give, those dots must be ignored, in trying to distinguish the single words of a PaleoVenetic text; they would condition the reader in the wrong way, as already highlighted by Bor et al. (1991). For example, in the inscription ETA.I.IO.N. it is recognizable the words e tai $i$ on, which mean "it is so and he"; and, in REKE.R.E.Ś., the words reke reč, which means "said a sentence". It is clear that the dots are not used to divide one word from another.

In this search for key words in the Paleo-Venetian inscriptions, for decades various scholars have found the solution by recognizing Slavic words or etymons first of all. We are grateful to Vodopivec (1941) who with his inventory of Venetian epigraphs, and to Bor et al. (1991) who paved the way in this direction, encouraging supporters of Paleo-Slav origin of the Paleo-Venetic language to continue the research in this direction. Moreover, paleographic and archaeological finds show that the Venetkens (name deriving from Slovenetkens) were of Illyrian-Danubian origin. They had migrated in various waves in the Italian north-east, above all by navigating on rivers or crossing the sea that will later be called by the Greeks Adriatikos, from the name of the port of Adria. Pauli (1891), when the Venetic alphabet was still considered northern Etruscan, already wrote "Inschriften den Illyrischen Venetern", inscriptions of the Illyrian Veneti.

\subsection{Global Understanding}

The meaning of the Tavola da Este was understood by translating the text on the 
basis of Slavic languages, with the only certainty of its importance. No preconceived thesis, no a priori conditioning on its civil or commercial, or religious, or other nature. We anticipate the global meaning that emerged from the translation of the text, so that readers can more easily follow the detailed analysis of each single line and word, carried out in the following paragraphs.

The emblematic plot would be the following: The "judge" (diaritor) of a Veneti settlement decides to punish, or test, an accused through the "potopleniem", that is, being thrown into the river in flood. The accused, if innocent, or if sincerely repentant of the crime committed, will not drown, he will be saved. Apparently this must have been a widespread custom among the Paleo-Veneti, or however in the anthropological context that produced the Tavola da Este.

Let me now put forward two hypotheses:

- in the first hypothesis (that it is an important public document) it would be a parable, that is, a narration that takes its cue from reality to transmit a moral and civil teaching. The teaching, in this case, seems to be the following: whoever is in good faith, an honest applicant, or a sincere repentant, will still be saved from the process to which he is subjected. Unlike those who, on the other hand, are liars and deceives, with fake prayers and acts of hypocrisy;

- in the second hypothesis (that it is an important votive object), it could be a thanks to a deity for having saved a man from drowning. Once saved, he will offer the divinity a luxurious votive plate, inscribed by an expert, where his story is told. Was this divinity Reitia, the divinity of all that flows, time, waters and writing? We will never know, due to the cuts in the outermost parts of the text. A sanctuary had been erected for her just in Este.

The text is however narrative, ethical in the first hypothesis, and religious in the second. Which is in itself a discovery, since it has always been stated that the Paleoveneti did not write narrative texts.

I am grateful to Ambrozič \& Tomezzoli (2003), who were the first to try to translate the Tavola da Este, for their numerous and valid suggestions in understanding this difficult, fragmentary and rare text both materially and semantically. If some of their proposals for interpretation do not convince me but the esteem towards them remains unchanged, this is part of the normal dynamic of the comparison of different interpretations of the protohistoric finds, all based on hypotheses. Even some translations of Bor et al. (1991) are questionable, but what matters are the method, the approach, the general criteria of their analyses.

\subsection{Analytical Understanding}

\subsubsection{First Line (The Outermost) of the Tavola da Este}

Hypothetical word division (based on Figure 3 and keywords DIARITOR SVAG BARO): M KUD E DIIARITORE SVAG (SONT)(...)(MOIS) DOTI E!NEI BARO $^{4}$.

${ }^{4}$ The square brackets contain hypothetical letters added by the translator. Round brackets indicate missing words, due to holes and other defects in the metal plate, or because they are cut. 


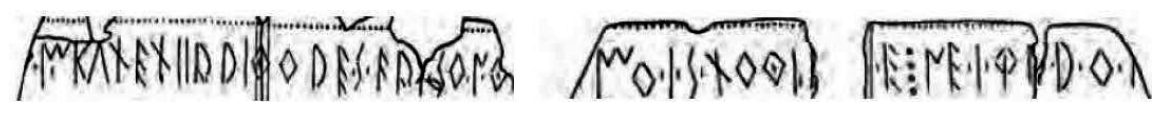

[O].M.KUDEDIIARITORE.S.VA.GSO.N.T (...) MO.I.S.DOTI(...).E:NE.I.BA.R.O.

Figure 3. First line (the outermost) of the Tavola da Este.

\author{
Literal Translation \\ $[\mathrm{O}] \mathrm{M}$ ? \\ where (KUD) \\ there is $(E)$ \\ a judge/referee (DIARITORE) \\ of quarrels (SVAG) \\ (SONT) (...) (MOIS)? \\ gives/is given (DOTI) \\ (...) to the individual (ENEI) \\ guardianship (BARO)
}

\title{
Current Translation
}

The presence of an referee/judge who examines the disputes offers to the individual protection.

\section{Text Analysis}

[O] $\mathbf{M}$ termination of the previous word, presumably of a Slavic male name declined in the instrumental case (corresponding to some functions of the Latin ablative, for example, in Russian, $s$ drugom, with a friend). Or it could be the termination, declined in the prepositive case, of a masculine adjective referring to the noun that follows DIARITORE, also in the prepositive, which would explain the ending "E"; in fact the nominative is DIARITOR (the prepositive case corresponds to other functions of the Latin ablative; eg, in Russian, $v$ dobrom gorode, in a good city). Unfortunately it is not known whether OM is the ending of a noun or an adjective, as the text is incomplete.

KUD means "where", in the Illyrian Slavic (in Croatian and Bosnian kud, in Serbian kuda) and Danubian languages, where it occurs in the variants $k d e$ (in Czech and Slovak) and kód (in Slovenian); in Russian kudà (motion to place) and in Ukrainian kudi. In Bulgarian and Macedonian it is kъde and kade. Vowel alternation is an ordinary phenomenon in Paleoslavian and Venetian languages, and not only, in which the vowels change in pronunciation, especially due to the tonic accent ("a" is pronounced unstressed "e"; "o" is pronounced "u, uo" but "a" if it is unstressed; " $e$ " is pronounced " $i$ " (as in Trieste the dizi, she says, in Venetian gavì, you have) or "je”. Ros' became Rus in ancient Russia; you becomes $v \boldsymbol{u}$ in Venetian; posto becomes puest in Friulian; the Venetian barufar derives from the Slavic borotsja, to fight, to quarrel; dux will become the doge in Venice; the Greek endings "os" and "on" became in Latin "us" and "um"). The "e" and the "o", then, are considered by linguists as allophone variations of the same sound (bene, well, from the Latin bonum-bono). Since phonemes historically precede graphemes, vowels, at the introduction of writing, were often tran- 
scribed as they were pronounced, without respecting their original spelling.

E means "is, there is, exists" (pronounced $j e$ ). The 3rd person singular of the verb to be has the form " $e$ " in Bulgarian and Macedonian; has the form " $j e$ " in Slovenian, Croatian, Bosnian, Serbian, Czech and Slovakian; "est" in Russian, "jest" in Polish. In the Slavic language family, the oldest are Illyrian-Danubian. The oldest Russian Chronicle (letopis'), the Chronicle of Nestor (11th-12th centuries) testifies to this, where it narrates that the apostle Paul of Tarsus went to preach Christianity in Illyria "where the Slavs originally lived". This is confirmed by 20th-century linguists, such as Alinei (2000).

DI(I)ARITOR(E) the one who examines/judges (presumably from the Greek verb $\delta ı \rho \nu \theta \mu \dot{\varepsilon} \omega$, diaritmèo, I enumerate, I examine, I judge). The Greek origin of this word is recognized by the typical prefix "dia" (dialectic, dialysis, diameter, diaspora, etc., corresponding to the Greek preposition $\delta \iota \dot{\alpha}$, dià, which means through, for, from one point to another), which it is certainly not Paleovenetic, and also from the etymon ritmòs, measure, manner. The Greek verb ritmizo means I put in order, I arrange. The ending "or-er" is not frequent in classical Greek, it appears in some common name (such as ák $\tau \omega \rho$, aktor, guide; $a ́ \sigma \tau \eta \dot{\rho} \rho$, aster, star); in abbreviated forms of nouns ending in -os, -es, and in some proper name, such as $\Delta \mu \dot{\eta} \tau \omega \rho$, Dmètor). In the ancient Venetian language it appears above all in the variants: "er-ar" (eg: pistòr, the baker; ekvupetar, who travels on horseback; bekèr, butcher). The two "I" in DIIARITOR, which are considered one for understanding purposes, can be explained: it could be a long " $i$ " (in Slavic languages there are two " $\mathrm{i}$ ", one short and one long). Another hypothesis: the second "I" actually goes together with the "A" in the Slavic vowel "ja". Third hypothesis: the reason for the two "I" is perhaps the Greek origin of the word DIARITOR; in which the " $\mathrm{i}$ " is pronounced rather elongated.

Why the Atestins of the 5th century BC would they have resorted to a Greek word? Greek was the richest language in Europe at that time, capable of expressing even complex, scientific, legal and socio-political concepts. Indeed, in the fifth century BC. dates back the so-called "turning point in classical Greek literature", due to the consolidation of the poleis (cities) and oligarchies, with great repercussions in the philosophical debate and in literature, including theater and historiography. And relations between Greeks and Veneti were frequent, primarily commercial, in particular through the ports of Altino and Adria. It can be assumed that a diaritor was elected by the assembly of the heads of the families of the village or burg (future city), in order to resolve any disputes and problems that arose in the daily coexistence of the community. Another important public role within the ancient Veneti communities was that of the meriga, which assigned to each family the common land to be cultivated partly for itself and partly in the collective interest (see under MERKA in the analysis of the text of the fourth line). In the text of the Tavola da Este the two roles appear separate.

SVAG means "of quarrels, disputes"; is the plural genitive of svađa (pronoun svagia), quarrel in the Illyrian and, in part, Danubian languages: in Croatian, 
Serbian, Bosnian svađa; in Czech and Slovak it is hádka; in Ukrainian it is svarka and, in Belarusian, svarycca means to quarrel. In Slovenian obsódba, and sodba in nediško, they mean judgment. Therefore the term DIARITOR, the examiner of disputes, could be translated "judge", or "arbitrator".

SONT (...) MOIS. It is not possible to hypothesize a meaning of these two fragments, separated by an entire vertical line of words, which was lost when the bronze sheet was cut to be reused.

DOTI means "give, gives": present of the Paleoslavian verb doti, to give, to offer. With ending of the 3rd person singular outgoing in $-i$, as in the Slovenian or Croatian or Bulgarian verbal voices misli, he thinks, govori, speaks, spi, sleeps, etc.). The verb dot $i$ is frequent, in the past form doto, in the sense of "has given, has been given", in the inscribed Paleovenetic dedications (eg: IK GOLTANOS DOTO LOUDERAI GLUVI KONII, Who drank [the thermal water] offered to Ludera a "deaf" horse, that is, one that does not obey commands, therefore unusable (4th century BC engraving on the edge and handle of a situla, Museum of Pieve di Cadore).

(...) ENEI means "to one" (to the individual, at the individual). In Slovenian, ena means one (as in Greek); jeden in Polish and jedan in Serbian; eden in Macedonian). In modern Slovenian, “a one" is called enemu; in Bulgarian na edin. ENEI presents one of the endings of the Slavic singular dative, which assumed -e still assumes -a depending on the case, the forms "e-i-ei-ai" (eg: Reitiai, to the goddess Reitia; Trimuziatei, to the god Trimuziàt). The four vertical points that appear after the first "E" of ENEI are probably not a linguistic sign, but of a technical nature, perhaps indicating the attachment of the bronze sheet to the support surface.

BARO means "guard, protection, defense". From the etymology of the Slovenian verb varováti, in nediško it is vàrvat, to guard, to keep. The alternation "v-b" (betacism), typical of Slavic languages, probably inherited from the Greek language which uses the grapheme " $b$ " to produce the phoneme "v" (eg: $B \alpha \gamma \alpha$, pronunciation vaga), caused the etymology to contract varo in bra: in fact, in Croatian, Serbian, Bosnian to protect is said braniti; in Macedonian brani; in Polish bronić. And also in Slovenian, defense is called obramba; in Russian, richer in vowels, oborona. BARO, object of the sentence, has a Slavic feminine ending in the singular accusative case in "o" (for example in doti raco, which means "to offer a duck"). Or it was a neutral gender name ending in "o" (as, for example, mesto, place; oko, eye).

The linguistic, lexical and morphological analysis of the first line confirms the Current Ttranslation already proposed: The presence of an arbitrator/judge who examines the disputes offers the individual protection.

\subsubsection{Second Hypothesis of Interpretation of the Word DIARITOR}

Accepting the proposal of Ambrozič \& Tomezzoli (2003) that DIARITOR is equivalent to DARITEL, "the offerer", the text would acquire the following semantic and communicative value: Where there is someone who offers [to the 
gods], (...) protection is given to the individual. This hypothesis would confirm the votive-religious nature of the Tavola da Este.

\subsubsection{Second Line of the Tavola da Este}

Hypothetical word division (based on Figure 4 and keywords: GNOS EKVO BOS VERIEOS PATTAPLANAM): OR E GNOS EKVO BOS MOLTEVE BO SEI VIDO !X! VERIEOS DIARITOR BOS DA NEI V PATTAPLANAM

Literal Translation

the judge/referee [DIARIT] OR

is $(\mathrm{E})$

repugnance (GNOS)

of the horse (EKVO)

barefoot (BOS)

in prayer (MOLTEVE)

will be seen (BO SEI VIDO)

credible (VERIEOS)

the judge/referee (DIARITOR)

down (DA NEI)

the barefoot (BOS)

in the river in flood (V PATTAPLANAM)

\section{Current Translation}

The judge [DIARIT] OR is like this: he refuses to ride a horse, he is barefoot and prays. The DIARITOR who knows how to decide whether an accused should be thrown into the river in flood will be considered credible.

\section{Text Analysis}

OR termination of the previous word, similar to DIARITOR, which is the only word coming out in "OR" in the whole fragment of readable text. A common name of a person is assumed; who is? Let's me assume that it is the DIARITOR, the arbiter of the quarrels. Let me try to verify this from the rest of the text.

E from the Slavic verb to be: it is (see $\mathrm{E}$ in the Analysis of the text of the first line).

GNOS in Slovenian means gnus "repugnance, rejection, disgust" (hnus in Slovak and Czech, but it is pronounced gnus). In Croatian and Serbian gnusan means disgusting, repellent. The original etymology is gnoj, manure, pus, widespread in all Slavic languages; in nediško it is gnojà, in Sorbian hnojiwo. The alternation of the graphemes "o" and "u", especially in pronunciation, has already been analyzed as an ordinary phenomenon (see KUD in the Analysis of the text of the first line).

EKVO is one of the typical words of the paleo-Veneti civilization and economy:

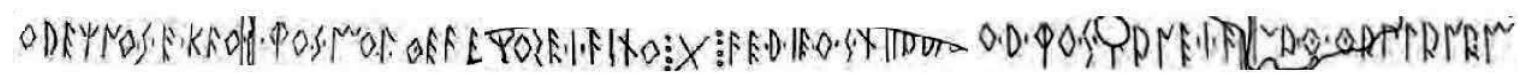
OREGNOS.E.KVO. BO.S.MO.L.TEVE BOSE.I.VIDO:X:VE.R.IE.O.S.DIIARITO.R.BO.S.DANE.I.VPAT.TAPLANAM

Figure 4. Second line of the Tavola da Este. 
the horse. The ancient Veneti (meant in Latin, inhabitants of the $\mathrm{X}$ regio "Venetiae", between the river Adda and the Croatian river Raša) were the best horse breeders of the time, much praised by the Greeks. In the 1st century B.C. Strabo complained that this their art was already in decline. They also trained wolf cubs as guards of their horses, intended for sale, for racing and as a weapon of war. So a horse was a capital, a sort of today's Formula One; losing or stealing a horse was a crime. The Paleovenetic term EKVO derives from a Paleoslavic etymology, which has remained in all the Slavic languages, in which the horse is called kon-kon'-konj (variants: in Czech kůň, in Slovak koňa, in Sorbian kón). It is recognized in the term EKVUPETAR, engraved in some pre-Latin paleovenetic steles (from Padua and Altino), formed by EKVO (on horseback) and PETAR (from put, walk). EKVUPETAR therefore means those who travel on horseback, or who make a long journey. Since the term EKVO was used by the Paleoveneti before Romanization (Boutet, 2021) finds it in the inscriptions of the ancient Danubian civilization of the 6th millennium BC, from the inscriptions of the Danube Civilization decoded?), it is reasonable to assume that the Latin equum derived and not vice versa. The "refusal of the horse" means a person of the utmost simplicity and living in poverty: the horse was a status symbol or of wealth or power. It was also a precious tool of war, which allowed to attack quickly, with all the impetus of galloping horses. In Greece the horses purchased from the Veneti were used only by aristocrats, whose role on the war scene was reduced by the "hoplitic reform" (of the infantrymen) of the sixth century B.C., thanks to which the infantrymen-peasants armed with spears, shields, helmets and greaves, became protagonists in the war, as much as the knights.

BOS means "barefoot". In the Illyrian, Danubian and even Northern languages, "barefoot, with bare feet" is said to be bos. Maintains the form bos (adjective and noun) in Slovenian, Croatian, Serbian, Bulgarian and Macedonian, Czech; in Polish it is bosy (adjective); in Russian it is bosoj (bosikòm, adverb: barefoot); in Ukrainian bosij; in Czech and Slovakian bosý (adjective) and naboso (adverb: barefoot); in nediško it is bosè, barefoot, etc. This is a very old custom; we went, and we go, barefoot not only out of poverty. Going barefoot is in itself an act of humility and penance. St. Francis walked barefoot. Think of the practices and rites of Burmese and Tibetan monks, of Buddhists and Hindus, of races and processions with barefoot participants, still in force even in some Italian regions or, in historically recent times, of "barefoot" religious orders such as the Franciscans and the Carmelites, reformed in the 16th century. Going barefoot is part of the DIARITOR's attitude of simplicity and poverty, a man certainly not looking for riches.

MOLTEVE MOLTEV means "of prayers" (in Slovenian, Croatian, Serbian, Bosnian molitev, in Russian molitv, in Czech modliteb). Molitva also means prayer in Bulgarian and Macedonian, while in Polish and Sorbian it is modfitwa. In nediško it is molitva. The ending "ev" of MOLTEV (E) is typical of Slavic plural genitives (eg: in Slovenian, bukev, of the beech trees; in Russian brat ev, of 
the brothers). However, the final "E" of MOLTEVE cannot be ignored as it appears in the engraving: it could be the termination of the prepositive case of the singular feminine noun, and mean "with prayer, in prayer" (on the prepositive, see the entry OM in the Analysis of the text of the first line). In this context, "in prayer" should be understood as a manifestation of devotion to the deities. The religious dimension was very intense among the Paleo-Veneti tribes, who interpreted natural phenomena as acts of superhuman entities, not all anthropomorphic. After all, the most ancient civilizations are the most religious, as theorized by the enlightenment philosopher Giambattista Vico: the first phase in the evolution of human knowledge is the religious one, in which everything is interpreted as manifestations of divine will, followed by the "scientific" one, which seeks to scientifically explain phenomena, followed finally by that of the "I", in which man overlaps reality, transforming and creating it (sometimes destroying it).

BO SE (I) means "will be", future of the verb to be (in the Slavic languages bit-byt'-bić-biti, etc.) in the third person singular. In Slovenian this future is bo $s e$, identical to what appears in the inscription. In Czech, Slovak and Ukrainian it is bude, in Bulgarian šče bŭde, in Russian budet, in Belarusian budze, in Polish będzie). It accompanies the past participle VIDO, which follows immediately after: the two verbs together mean "it will be seen, held".

VIDO means "seen, perceived, held" (contracted past participle of the verb videt'-videti: in Croatian vidio; in Serbian and Bosnian videno; in Slovenian and Macedonian videno; in Bulgarian vidjano). In the Illyrian Slavic languages, the termination of the past participle contracted in "o" from "eno, ano" is frequent (eg: rečeno, said; delano, done; končano, concluded, etc.). An analogous phenomenon occurred in past participles, Paleovenetic and Venetian dialect names and adjectives, with the contraction in "o" of the termination "ato", vulgar of the Latin atum-atus (eg: sabo, from sabato saturday; Kamalo from Kamalato, equipped with masonry. The terms in the Ruzante theater are famous as sold $\dot{\boldsymbol{o}}$, soldato soldier, dizgrassiò, disgraziato, unfortunate, guagnò, guadagnato, earned). In this specific context, BO SE VIDO, will be considered, appears as a future with a final value: "to be deemed" or "to be considered".

IX probably it is not a linguistic sign, but a technical one, perhaps of the attachment of the bronze plate to the support surface, or to other similar plates. The same sign will be found elsewhere in the text, even in the form of simple groups of dots arranged vertically.

VERIEOS means "in good faith, credible". It is a singular masculine adjective. It derives from the etymology "vera", faith (in Slovenian and Russian vera; in Croatian, Serbian, Bosnian vjera; in Macedonian vjerata; in Bulgarian vjara and in Polish wiara. "Os" is a termination, both nominal and adjectival of Greek, frequent for example in adjectives indicating relevance (adriatikòs, which concerns the port of Adria; venetikos, which belongs to the Veneti), remained in the languages of Europe, perhaps with the fall of the final "s" (e.g.: from isos, isos- 
celes, from archaios, archaeologist, from kalos, calligraphy) It being understood that even the Slavic languages have adjectives and participles ending in "os" (eg: bos, barefoot; goltanos, after having swallowed).

DIARITOR is the arbitrator/judge of disputes (see in the Analysis of the text of the first line).

BOS the barefoot (see above) in the sense of accused, who appeared in court barefoot, in a humble and penitent attitude.

DA NEI do so! Da naj (pronounced daner?) in modern Slovenian ja naj is a concessive and even wishful adverbial expression (that you do it like this, maybe you do it like that, that you let yourself be done). It is governed by verbs of will such as "decide, decree, establish that" or similar. The term is composed of $d a$ (abbreviation of the Slavic tak. like this. It then acquired the meaning of yes, of course) and naj-neka-niech, in the various Slavic languages, an ancient permissive expression (be permitted). In Slovenian, " $d a$ " has recently been replaced by “ $j a$ ". Variations in other Slavic languages: in Croatian, Serbian, Bulgarian and Macedonian it is da neka; in Czech ano nech; in Polish tak niech; in Ukrainian it is tak nehaj. The original meaning of DA NEI is: so be permitted to do, go ahead! What is allowed to be done with the barefoot can be deduced from the immediately following words V PATTAPLANAM.

V PATTAPLANAM means "in the river in flood".

$\mathrm{V}$ means in, inside a. It is a preposition that expresses state to place (followed by prepositive case) and motion to place (followed by accusative case), common to all Slavic languages (in the city: $v$ gorode in Russian; $v$ mestu in Slovenian; ve městě in Czech; $v$ misti in Ukrainian), also in the variant " $u$ " (in the city: u gradu in Croatian, Serbian, Bosnian; ŭ goradze in Belarusian) and "w" in Polish and Sorbian (in the city: $w$ mieście).

PATTAPLANAM term very similar to the Bulgarian potopleniem which means "by drowning", ending in the instrumental case. In nediško it is potopienjem, in Slovenian utapljanjem, in Croatian and Serbian utapanjem. In Bulgarian, potapjabam means to dive, immerse, sink; in Croatian it is potonuti, in Slovenian it is potoniti. In Bulgarian and Macedonian, potop means flood, mass of water; in Slovenian, Croatian, Bosnian and Serbian poplava. PATTAPLANAM is composed of potop, a mass of water that invades and pla, the etymology of Plava (ancient name of the river Piave) and the Slavic verb plàvat'-plavati, to navigate, to swim. However, it expresses the idea of someone or something thrown or overwhelmed by a water course in flood. It is normal for the "o" of potoplèniem to be pronounced "a", due to the akanie phenomenon widespread in Slavophony, for which the unstressed "o" are pronounced "a" (eg: in Russian gòrod, city, si says gorrad; the surname Mussorgsky is pronounced Mussargsky).

Was this potopleniem the punishment for a crime? Or some sort of test to which a suspect, an accused person was subjected? If he had been able to save himself from the waters of the river, would that have meant that, however, the deities were propitious to him, as innocent, or sincere repentant? A valid, trust- 
worthy DIARITOR (referee-judge) had to be able to assess whether or not an accused was subjected to punishment or the test of potopleniem.

The linguistic, lexical and morphological analysis of the second line confirms the Current Translation already proposed: The [DIARIT] OR (referee-judge) is like this: he refuses to ride a horse, he is barefoot and prays. The DIARITOR who knows how to decide whether an accused should be thrown into the river in flood will be considered credible.

\subsubsection{Second Interpretation of the Terms GNOS and BOS and, by Logical Consequence, of V PATTAPLANAM}

(...)OR AND GNOS assuming that GNOS does not mean "repugnance", but derives from the verb goniti (Slovenian and Croatian) gonjàt (Russian) gonja (Bulgarian) gonič (Polish) honit (Czech) would mean "chased, pushed, chased away, carried away" (in Croatian ti gonišs, chase, to hunt; in Czech honišs se; in Polish gonisz). The verb gonjàt-goniti when referring to a horse can mean making it run to the limit (in Russian we say ja gonjù mašinu, I run hard in the car). Hence the archaic Venetian dialect expression "el caval/cavało de Gonèła" which indicates someone always in a hurry, exhausted by so many races. GNOS, in this case, would have an adjectival or past participle termination singular in the Greek "os" and auxiliary "E" (je). Nominal, adjectival and verbal Greek endings are not uncommon in Paleo-Venetic inscriptions (see VERIEOS in the Analysis of the text of the second line). It could also be a present tense, with the subject "you". "To push away, drive away" a horse means to use it in an improper and harmful way? Steal it? Take it away from the community? The situation would be completely different compared to the first translation hypothesis: it would be a horse thief, which the DIARITOR (the referee/judge) must judge. In the light of this hypothesis, the mysterious initial word ending in OR would acquire another meaning, different from DIARITOR: is he guilty of some crime, an accused who must prove his innocence? OR could stand for VOR, from the Greek $\varphi \omega \rho$, for, thief (from this etymology derive, in Russian, vor which means thief and vorovat', to steal; in Lithuanian vógti, to steal; in Estonian varas, thief; in Slovenian orópati, to rob (from vorópati; in Polish wor means sack; in Slovenian, Croatian and Bosnian sack is vreča-vreća, from the etymology vre-ver, which Preobraženskij (1959) compares to the etymology vor).

But OR could be the termination of KATEGOR, the accuser (in Greek

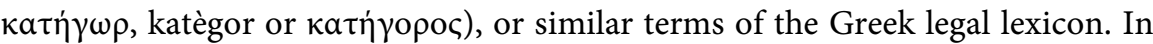
this case, the sentence would mean: the accuser [claims that] he stole a horse (or took advantage of it). The situation would be the following: he has stolen a horse, or has misused it to the detriment of the community, and must answer for it. The adjective VERIEOS would mean, in this second interpretation, "honest, sincere, in good faith". Of course, BOS and V PATTAPLANAM would also change their meaning in the hypothesis that E GNOS means "kicked out, taken away", as follows:

BOS barefoot (see the first Interpretation hypothesis). In the context of the Tavola da Este it can be assumed that a horse thief, like any accused, presents 
himself in court barefoot and pleading. Therefore "the barefoot" would be, in the context, synonymous with the accused to be judged.

V PATTAPLANAM in the river in flood. This meaning is connected to the second translation hypothesis of E GNOS, he took away, hunted, persecuted. Stealing or damaging a horse was a serious crime, given the importance of horses in the Paleo-Veneti economy. We recall that drowning represented the most widespread capital punishment among the ancient peoples of Eastern Europe. In Russia, for example, although applied in very rare cases, it was suspended only in 1744 by Tsarina Elizabeth I. It consisted in closing the condemned man in a sack, to throw him into the river. Drowning as a capital punishment was also in force in ancient Rome, for parricides. Traces of it can be found in the sentences of the Council of Ten of the Venetian Republic up to the 17th century: the condemned was thrown into the lagoon locked up in a sack or cage. Rubini (2010) mentions cases of death sentences by drowning inflicted to heretics (therefore starting from the 16th century) and accomplices in attacks against the State. It can be assumed that this type of condemnation was a legacy left to the ancient Venetians, who applied it many centuries before the birth of Venice, and who called it V PATTAPLANAM (potopleniem, for drowning). But death sentences for drowning were actually very rare cases. Although stealing or losing, or damaging a horse were serious offenses among the Venetians of the 5th century $\mathrm{BC}$, these crimes did not deserve such a penalty. Instead, it could be a simple punishment, or a test to which the guilty (in this case, the horse thief) were subjected, thrown into the river, naturally not closed in a sack! If they managed to save themselves from the water, they were judged innocent, or repentant sincere, credible, and forgiven. As always, we proceed by hypothesis.

In this second hypothesis (E GNOS means "took away") the second line will have the following Current Translation: Someone (a thief?) took away (or "The accuser: You took away") a horse; he is barefoot, pleading; in order for him to be considered credible, the DIARITOR (referee-judge) will have him thrown into the swollen river.

\subsubsection{Third Hypothesis of Interpretation of the Second Line of the Tavola da Este}

In harmony with Ambrozič \& Tomezzoli (2003) interpretation of the first line, in which DIARITOR stands for DARITEL', that is an offerer to the deities, I hypothesize the following meaning of the second line of the text: The offerer [to the gods] is like this: he goes on foot (he refuses to ride a horse), he is barefoot and in prayer. If he is deemed to be a sincere offerer, he will bare it; even if thrown into the swollen river, [he will be saved by the divinity to whom he is devoted].

\subsubsection{Third Line of the Tavola da Este}

Hypothetical word division (based on Figure 5 and keywords: VALGAM LOK LOS PERIKON VONIN): E TAI I ON VALGAM TOOM MNIO PEDON E LOK VIL LOS DOUKAI PERIKON VONIN KOM PROIVOS 


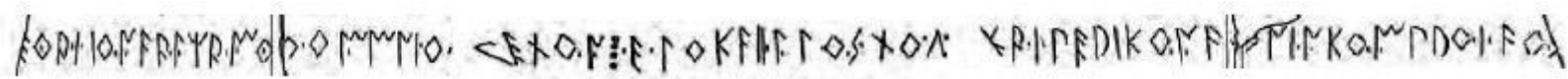
ETA.I.IO.N.VA.L.GA.M.TO.OM.MNI.O.PEDO.N.E.LOKVI.L.LO.S. DO.U. KA.I. PERIKO.N.VONI.N. KO.M.PRO.I.VO.S

Figure 5. Third line of the Tavola da Este.

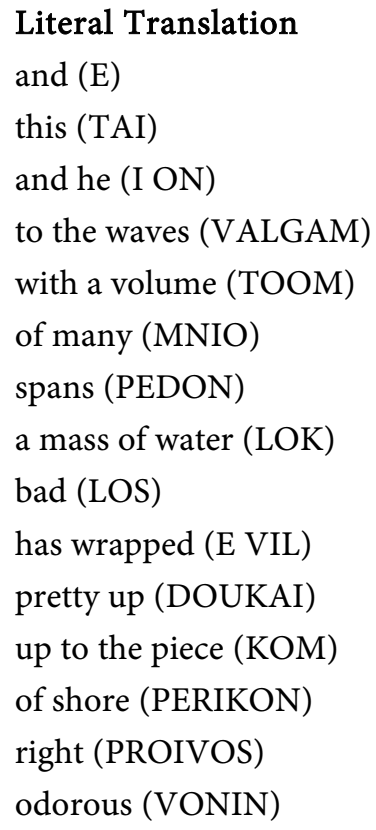

\section{Current Translation}

So it happens. And he [finds himself prey] to the waves of a volume of several spans. A threatening mass of water [him] has enveloped him as long as he [does not reach] the good part of the bank (quay), which he smells of aromas.

Text Analysis

$\mathrm{E}$ is present of the verb to be: è (see the item $\mathrm{E}$ in the Analysis of the text of the first line).

TAI means "this". In Croatian taj and in Slovenian tá mean "this"; in Polish ten, in Sorbian to, in Russian eto-eta. In nediško, tak also means "such".

I ON means "and he". The conjunction "e" sounds "i" in most Slavic languages (in Bulgarian, Macedonian, Serbian, Croatian, Polish, Russian, Belarusian, Ukrainian), and "in" (in Slovenian); a, in Czech, Slovak, Sorbian; an, in nediško. $\mathrm{ON}$ is the masculine personal pronoun subject in almost all Slavic languages, they are very similar to "on" ën (pronunciation ion) in Belarusian, wón in Sorbian, vin in Ukrainian, which may seem strange: the Ukrainian language tends to replace the vowel "O" with " $\mathrm{i}$ " (eg: moj becomes mij, sok becomes sik).

VALGAM means "to the waves", that is prey of the waves. The term is presented as a plural dative (from the typical Slavic ending -am) of the noun val, which means "wave" in many Slavic languages: in Slovenian, Croatian, Bosnian; in Bulgarian it is vblna; in Belarusian chvalja; in Polish fala, with ordinary alternation of the fricative consonants " $v$-f" (in German, for example, the " $v$ " is normally read " $\mathrm{f}$ "); in Russian volnà with vowel alternation "a-o" (pronounced valnà); in Sorbian wołma. From the etymology val-fal derives the toponym Falzè 
di Piave (fraction of the Municipality of Sernaglia, just over $12 \mathrm{~km}$ from Treviso), which refers to a precise point of the course of the Piave, always undulating (val-fal: wave), even when the river is dry. This site is historically known: here the Cadore raftsmen, which transported the timber destined for the Republic of Venice, delivered it to other men in charge of delivering it to San Donà di Piave or directly to Venice.

VALGAM could be, instead, the Croatian verb valjam, which means "precipitate, roll down" (in Czech válim se, in Slovak valím sa. In Russian valìtsja means to fall; in Polish walič means to break down, to throw down, and vali means "to collapse". In Bulgarian vali "comes down", referring to rain or snow). From the verb to the reflexive form valit'sja derives the Venetian dialect expression skravàssa, which means it rains heavily. It is formed from the adverb krajno, at most, and from the verb vałizza, comes down. With the addition of emphatic "s", fall of "no", with " $\mathrm{P}$ " evanescent and "zz" pronounced "ss", in the Venetian style. In that case I ON VALGAM would mean: And [he shouts]: "I'm rolling, I fall", or something similar. This second hypothesis would not, however, change the meaning of the remaining text, of the accused thrown into the river, who manages to swim to the "right" part of the quay.

TOOM (pronounced TOUOM-TOVOM) means "with a load". The termination suggests a Slavic noun declined in the singular masculine instrumental case (on the instrumental case, see the entry OM in the Analysis of the text of the first line). Accepting the interpretative proposal of Ambrozič \& Tomezzoli (2003), we recognize the contraction of the noun tovorom, which means "with a load, a volume": in Russian, Bulgarian, Macedonian, Slovak, Belarusian tovar; in Polish towar; in Croatian, Bosnian, Serbian, tovariti means "to load", in Slovenian it is tovóriti; in Sorbian tłočić, pronounced tuočić). Therefore it would mean "with a load" or "of the volume of".

MNIO (MNOIO) PEDON means "of many spans". Let's assume that MNIO (MNOIO) is an archaic form of MNOGO, an adverb meaning "much", used in most of the Slavic languages (in Bulgarian, Macedonian, Serbian, Croatian and Russian mnogo; while some South Slavic languages instead of mnogo they prefer puno, da pòlno, full, packed, and veliko, greatly). According to Preobrazhensky (1951), the adverb mnogo, originally ъnоъ, originated in Eastern Slavophony. Some of its archaic local forms: mlogi, lower Sorbian; muohy, in Czech. PEDON should be a plural genitive, in fact mnogo holds the genitive case of the noun. It could mean "of spans" (ped, pédenj in Slovenian mean "span", pedín(a) in nediško; it is pjad' in Russian and pedja in Bulgarian; in Czech it is rozpětí; in Slovenian pést means "a fist", in the sense of the quantity it contains; in Czech it is pěst, in Slovak päst"; in Polish it is pięść). Razpon which means "span" in Croatian, Bosnian and Serbian, is actually a contraction from the original raz-

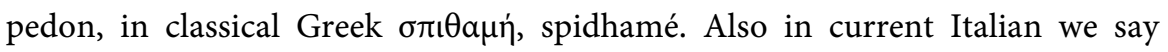
"misurare a spanne" to indicate a completely approximate, improvised measurement, as if to say "by eye". In this passage of the text, more poetic than scientific, the word ped, span, must be understood in this sense, not as a true 
unit of measurement. Used by the ancients, it was equivalent to the distance between the tips of the thumb and little finger of an open hand. The span was not a unit of measurement of the Romans, who used, referring to the hand, the finger and the palm. It can be hypothesized that MNIO, on the other hand, is the contraction of the current term mnenje (opinion); it would mean "apparently, I think". The sequence would mean: "prey to the waves, a volume, I think, of [various] spans". The rest would not change.

E VIL the present tense of the verb to be $\mathrm{E}$ (see item $\mathrm{E}$ in the Analysis of the text of the first line) has the function, in this case, of auxiliary of the past verb VIL that follows immediately after. In fact, in South Slavic and partly Danubian languages, the past is formed with the past tense (called "descriptive") preceded by the verb "to be" as an auxiliary (eg: in Czech udělal jsem means "I have done", where jsem means "I am"; in Slovenian on je naredil, he has done, je means "he is", auxiliary of the past naredil). VIL it is easy to recognize as a past with a singular masculine subject of the Slavic verb viti, to wrap, to cover (in Slovenian zaviti means "to wrap, to cover"; in Polish zawinąć; in Bulgarian it is uvivam; in Croatian ovitak is the cover). The ending " $\mathrm{L}$ " is proper to the past tense of Slavic verbs with a singular masculine subject (eg: on dumal, he thought; je pomislil Stane, Stane thought). Considering the etymon VI of the verb viti, the translation of E VIL will be "he wrapped, he covered". What is the subject of this verb? LOK, of course (see below).

LOK the etymology LOK-LUK is widespread in Slavic languages, with two different meanings, but both of which can be traced back to water: on the one hand, it means wet expanse, that is, meadow, which is damp, wet, by definition. If the meadow is not wet, it dries up and is no longer a meadow. Well, meadow is said in Slovenian lóka, in Polish ląka, in Sorbian łuka; in Russian, Belarusian Ukrainian lug, Czech louka, Slovakian lúka. On the other hand, the Slavic term that we translate into Italian as "liscivia", but which actually means a mass of running water (ignoring the solution of wood ash in boiling water) is in Slovenian and Polish lug; in Bulgarian and Macedonian luga; in Czech louh and Slovak lúh (the two final "h" are pronounced "ch"); in nediško it is lùh; in Croatian, Bosnian and Serbian lužina. Moreover, it is the etymology from which the name Lužica derives, Lusatia ${ }^{5}$. In our opinion, therefore, considering the ordinary alternation of vowels "o-u", LOK means "mass, expanse of water".

LOS means "bad, insidious, malignant". It is an easily identifiable term in the Slavic languages: bad is loš in Croatian, Serbian and Bosnian; lošo in Bulgarian and Macedonian; zlo in Czech, zły, in Polish. In Russian and Polish zlo means "evil". Two terms typical of the Venetian dialects also derive from this etymology, slosso (rotten) and lofio (of bad quality, poor; adjective used to indicate people or things of little value). Referring in this context to the waves of a river in flood, the adjective expressively expresses the idea of the danger they ${ }^{5}$ Cremation is such a typical feature of the "civilization of Lusatia", that is, of the Paleo-Veneti, that many historians fix the arrival of the first Veneti (Slav-speaking) tribes in present-day Russia, primarily based on the appearance of cremation. 
represent for a man, even death. It could be translated as "threatening" speaking of a mass of water. Unless LOS is equivalent to the Venetian slosso, meaning "rotten". It could be a swampy part of the river. The normal construction of the sentence today would be: E VIL LOS LOK (did a threatening or putrid water envelop it?), with the adjective (LOS) placed before the name (LOK). Placed after, it is highlighted.

DOUKAI dokàj means "enough" in Slovenian; it derives from do (up to) and kaj (what?); in Croatian dok means "while" (for as long as); "how long?" it is said dlouho jak, in Czech; dodeka in Macedonian; długo jak in Polish; dolgo kak in Russian. Dokle in Croatian and Serbian; doklèr in Slovenian; dok, dokar in nediško mean "until". In this context, DOUKAI means "enough, until"; it can be translated as "as long as, up to".

PERIKON VONIN are presented as qualifying adjectives referring to the noun that follows KOM, piece, part. As a rule, in Slavic languages the adjective precedes the noun. In the first, PERIKON, we immediately recognize the Slavic word bereg which means "shore", with hardening of the consonants (the labial "b" in "p" and the guttural "g" in " $k$ "). From bereg, in its time, the Slovenian, Croatian and Serbian term peron, quay, equipped shore, sidewalk, is derived; in Bulgarian it is howevern and brjóh in Sorbian. Russian perròn and Polish peron refer only to railway station platforms. The Greek ikon neutral suffix expresses relevance: it means relative to the bank or quay, shelf at the foot of the river bank, where boats (burci or similar flat boats of the Venetian river and lagoon tradition) land and agricultural products and goods are deposited. It is useless to reiterate how important the river was for the Paleo-Veneti communities: it was the source of life, the main transport and communication route (see the $\mathrm{Mu}$ seum of the great rivers of Rovigo). But it also caused terrible floods, so villages were built away from rivers; the small towns, on the other hand, the future cities, which arose as markets and fairs, or around places of worship, developed right on the river bank, also to transport passengers and goods. Este itself arose from the Bronze Age as a village on the Adige river, in paleoveneto Vadys, from the Slavic vodà (pronounced vadà), water, with a Balticoslav ending -ys, became a notable writing center, then a Roman colony in the second century. B.C. It was so important in the Middle Ages that it also dominated Ferrara, whose lords, the Este family, came precisely from Este. The second adjective, VONIN has an unmistakable etymology: VON means aroma, perfume. In Slovenian vonj means aroma, perfume; in Polish woń; in Sorbian wóń; in Slovak vòňa; in Czech vůně; in nediško is uònja. In Croatian, Serbian and Bosnian "fruit" is voće, and in Macedonian ovošje, perhaps the name derives from the fragrance of the fruit? The Russian von', on the other hand, has the negative meaning of "unbearable stench". That typical Paleo-Slavic and Paleo-Venetic nominal and adjectival suffix "IN" expresses quality, way of being, origin (eg: zgarbelìn, cispa; casełìn, grocer; Kadorìn, del-dal Cadore; Mount Kanìn, which drips; Mašin, di Maša , diminutive of Marija). Therefore VONIN means "fragrant, aromatic". 
KOM the term instinctively suggests the Croatian, Serbian and Bosnian komad, which means "a piece", even if it is not reflected in other Slavic languages (piece is called kos in Slovenian, kus in Czech and Slovak, kusòk and čast' in Russian; kъs or parče in Bulgarian, sztuka in Polish, tok-tòko in old Venetian, etc.). In nediško the verb komadat means "to look after the animals, the cows" and komadàn means "looked after, tidied up", always speaking of animals. Other solutions are not seen.

PROIVOS accepting the proposal of Ambrozič \& Tomezzoli (2003), PROIVOS would be a variant of the etymology PRAV, with important vowel alternation A-OI (as, for example, in the toponym Codroipo, from "Quadrato", Friulian fortified town with a quadrangular shape), with the meaning of "right, good" (in Slovenian prav; in Czech and Slovak správny; in Sorbian prawy and in nediško it is pràv-pràvi; pravo is used, with the same meaning in Russian, Bulgarian, Macedonian and Ukrainian; in Polish is sprawiedłiwy). It would refer to the "good" part of the quay that smells of aromas of plants and fruit, or perhaps the flavors of a banquet set up for some ritual. "Good" also in the sense of "the right one", where you can climb, coming out of the water. It cannot be excluded, however, that PROIVOS derives from the Greek preposition pro (front), indicating that part of the quay or pier, which normally protrudes from the shore, to allow boats to dock. It would mean not so much "right, good", but "protruding" from the shore, therefore easier to use for those emerging from the water.

The linguistic, lexical and morphological analysis of the third line confirms the Current Translation already proposed: So it happens. And he [finds himself prey] to the waves of a volume of several spans. A threatening mass of water has enveloped [him] until [he reaches] the good (or "protruding") part of the bank (quay), which he smells of aromas.

\subsubsection{Fourth Line of the Tavola da Este}

Hypothetical word division (based on Figure 6 and keywords: MERKE VAN VENEV KENON): I MERKE DA (T) L (...) U TEI DE KOME I DIE I K VAN VENEV I SPAI VERO KENON

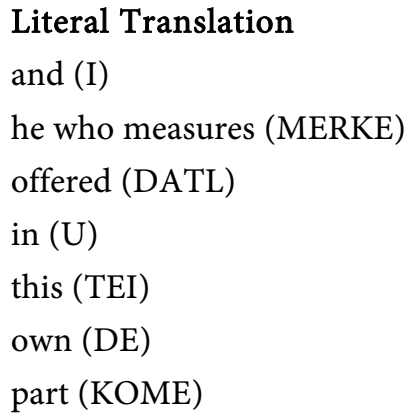

Figure 6. Fourth line of the Tavola da Este. 


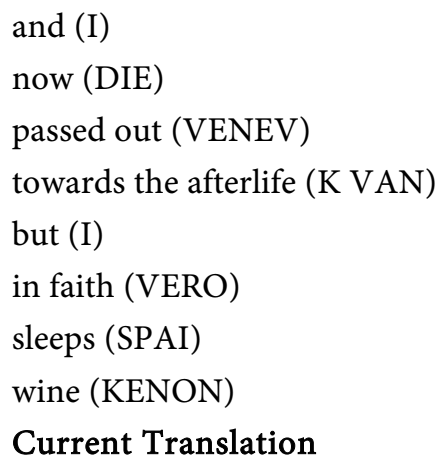

And the meriga offered wine, right in this part [of the quay], even to him now more dead than alive, but in truth he is sleeping.

\section{Text Analysis}

I conjunction "and" (see the item I ON in the Analysis of the text of the third line).

MERKA (pronounced mèrke) is the one who measures, who calculates the right doses. It is the same etymology of meriga (with the typical Slavic nominal suffix "ka", sweetened to "ga"). The meriga, elected by the ancient Venetian communities, had the task of calculating and assigning to the heads of the families the part of common land to work and the days to devote to the forest and other public works in the interest of the community. The name derives from mera, measure (in Croatian, Serbian, Bosnian mjera means measure. In Slovenian it is méra, in Russian mera, in Macedonian merka, etc.). Measure is in Croatian and Serbian mjeriti, in Polish mierzyć, in Slovak merat', in Czech měrit. In nediško the verb mérkat means to observe, to make an accurate visit. It is an etymology present in all Slavic languages; the term merka has been venetized in meriga. In central-northern Slavic communities, the term starosta was preferred (the oldest, that is, the elder, understood as "the sage of the village"). After the year 1000, the meriga progressively transformed into mayor in the municipalities of Veneto and Friuli, elected by the vicinia (in Slavic, sosednja), or assembly of the heads of families, expanding his powers. In the twelfth century, he had become the country's highest authority. In addition to the use of common lands, he regulated the collection of taxes, the administration of justice, the control of public works and merchant traffic, the list of recruits, etc. The name meriga still remains the president of some Cadore communities and, in the marigo form, was used in the Friulian communities. From this derive the French le maire, and the Irish méara, the mayor. In the context of the Tavola da Este, it could be precisely the meriga atestino offering wine on the quay, as we read in the rest of the fourth line, perhaps on the occasion of a rite or the celebration of the successful outcome of the potopleniem.

DA(T)L means "gave". It is an archaically conjugated past tense, which preserves the consonant of the infinitive ending "T". Today it would be DAL, not DATL. Perhaps followed by a letter "G", but not perfectly legible.

U TEI DE KOMEI right in this part (of the quay). 
V TEI: in this (see the item TAI, in the Analysis of the text of the third line and, for the preposition "V-U" in the item V PATTAPLANAM, in the Text Analysis of the second line).

DE corresponds to že, in some Slavic languages it means "just, precisely, this thing here". It is an expression of confirmation and reinforcement, a contraction of Da je, so it is, this is (eg: in Russian pojdì že; in Polish idźže, go away!)

KOMEI means "piece, part", is declined (see KOM in the Analysis of the text of the third line).

DIE I means "now even".

DIE is equivalent to the Slovenian že, already, by now, in Slovak už; in Russian užè; in Ukrainian vžè; in Czech již; in Polish już.

I conjunction "and" (see the item I ON in the Analysis of the text of the third line) can also mean, even, as in this context.

$\mathrm{K}$ VAN towards the afterlife. $\mathrm{K}$ is an old Slavic preposition that expresses direction towards someone or something (e.g.: in Russian idù $\mathrm{k}$ vračù, I go to the doctor; in Slovenian k babici, to go to the grandmother; in Slovak k babičke, towards the grandmother; in Croatian and Serbian k (a) baki). In Bulgarian it is $\mathrm{kbm}$. Normally the dative case holds, here not respected. VAN is a concept belonging to the Balticoslav mythology. It represents a kind of paradise, of harmony in the world of the dead. VANI were the Scandinavian gods associated with peace, love, the joy of living. It should not be forgotten that the Veneti for Pliny, Tacitus, Claudius Ptolemy and other great Greco-Latin historians and geographers resided between the Adriatic and the Baltic seas, that the gulf of Danzica was called "veneticus sinus", the gulf of the Veneti (that is of the Slavophones). So they belonged to the Balticoslav culture. To be precise, we should say that Paleo-Venetic belongs to the Balto-Slavic language family. It seems that the surname Vanin, typically Venetian, derives from VAN, from the unmistakable Venetic quality suffix "IN" (see the entry VONIN in the Analysis of the text of the third line). It would mean, based on the etymology, harmonious, peaceful, sweet, beautiful.

VENEV means "withered, wasted" and, referring to people, weakened, without strength. In Slovenian ovenel; in Croatian, Serbian, Bosnian uvenuo; in Slovak zvädnutý, in Polish zwiędły, in Russian vjanutyj. It is the same etymology of the Venetian viapo-fiapo, in Furlàn flap, flapit, without strength, withered (alternating “ $v-f$ "). Presumably, from it derives, keeping the same meanings, the French fané, withered, which in allegorical language can also be referred to people.

I VERO means "and/but in faith, frankly". Adverbial expression from true Slavic, faith, in Bosnian Croatian and Serbian, in Slovenian; in Polish wiara; in Bulgarian wjàra (see under VERIEOS in the Analysis of the text of the second line). The ending in "o" can be justified with the adverbial function of the adjective. In fact, in Slavic languages the neutral adjectives (ending in "o") act as adverb (eg: chorošò, bene; krivo, falsamente; vero, faithfully to reality). 
SPAI means "sleeps". It is the present tense, with ending "i" (see DOTI in the Analysis of the text of the first line) of the verb SPAT'-SPATI, to sleep (in Slovenian and Bulgarian spi, in Croatian, Serbian and Bosnian spava, in Czech and Slovak spí, in Polish śpi, in Russian spit; in Sorbian sleeping is spać. In Trieste, where in the dialect many Slavic terms or of Slavic origin are used (eg: bàba, mùlo, zimòn, brìvez) it is said “Che spavada”, to say “what a sleep!”).

KENON in Veneto KENO is a slang and mythical word, still used today, to say "wine". It is cited by both Emanuele Bellò and Walter Basso in their Venetian language dictionaries. It is not used in the Belluno area, in Trentino, in Friuli. In the Paleo-Venetic sanctuary of Meggiaro (in the province of Padua, S-E of Este), active between the VII and III centuries BC, the term was found inscribed in a lamina in the shape of a ship, perhaps to say that the cultivation of wine comes from afar. More than six hundreds of grape seeds and fragments of grape seeds have been found on this site. Which makes one think of vineyards, but also of the cult of wine, perhaps to a divinity linked to it. It was the Greeks who spread the cultivation of vines and the use and trade of wine in Europe. The

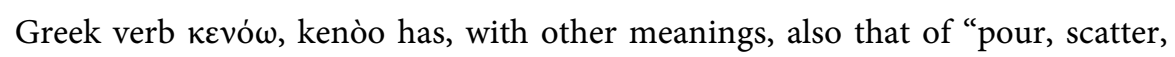
empty". Conjugated to the imperative (kene, versa!), or the Greek adjective kenòs, empty (neutral, kenòn) in reference to the container to be filled, they could be the origin of KENON-KENO, the wine of the Veneti. The etymology KEN (from the Greek $-\gamma \varepsilon v$, gen, lineage) is used in the Paleo-Venetic language also in a completely different meaning: in the sense of ethnicity; for example in the first written indication of the name of the ancient Venetians, which is VENETKENS, (Archaeological Museum of Vicenza) perhaps from the 4th century. BC, presumably from Slovenetkens, a Slav-speaking ethnic tribe. In the context of the Tavola da Este wine is offered to celebrate and to try to revive that poor man who saved himself from drowning, but who seems to be dying. Precisely in that part of the "odorous" quay (VONIN; see in the Analysis of the text of the third line) where perhaps a rite was set up, with sacrifices to the gods and roasted meats.

The interpretation proposed by Ambrozič \& Tomezzoli (2003) that DIARITOR stands for DARITEL', "an offerer to the gods" (see second line of the text) does not change the meaning of the third line: a sincere offerer is saved from drowning.

The linguistic, lexical and morphological analysis of the fourth line confirms the Current Translation already proposed: And the meriga offered wine, right in this part [of the quay], even to him now more dead than alive, but in truth he is sleeping.

\subsubsection{Fifth Line of the Tavola da Este}

Hypothetical word division (based on Figure 7 and keywords: REKE KRIVIN): REKE REŚ D (...) [M] OLTEVE BO SE I PO II KRIVINE A.:X:DIA (...)

\section{Literal Translation}




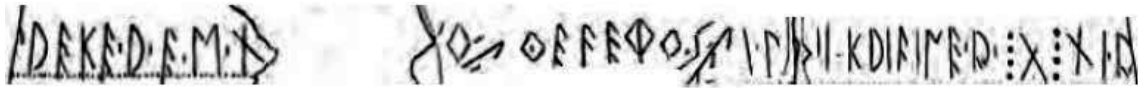 \\ REKE.R.E.Ś.D(.

Figure 7. Fifth line of the Tavola da Este.

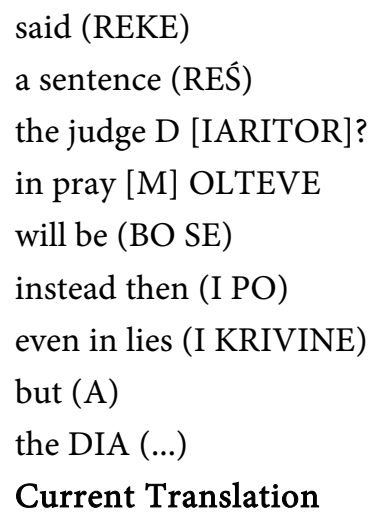

He made a speech (the DIARITOR, the judge?): Maybe he prays a lot, but then he also deceives, but the DIA (...)

\section{Text Analysis}

REKE means "said, has said". In Slovenian rekel je, in Croatian rekao je. The etymology rek-reč unites many Slavic words related to the word, to the act of speaking: reći in Croatian, réč in Slovenian, rèč in nediško, rěčeć in Sorbian, they mean "to say, to speak"; in Russian rèč is the word; rečenica means phrase, in Croatian, Serbian, Bosnian and Macedonian. But it also shares them with a typical Slavic word which is reka-rekà-rijeka, the river. Just as reč' is a flow of letters and sounds, of words, so reka is a flow of flowing water. It is no coincidence that the Paleo-Venetic deity Reitia protected the flow of water, time and writing. The etymology re is Greek, from the verb $\rho \dot{\varepsilon} \omega$, reo, which means to flow in the philosophical sense that "everything passes, everything runs away". Marinetti (1993) reads PREKE, instead of REKE, with an initial "P" of which, however, there is no certainty.

REŚ means "sentence, speech" (for the etymology see REKE). In Slovenian reč can mean "one thing".

D perhaps is the initial letter of DIARITOR, the referee/judge.

[M]OLTEVE in prayer (see the same item in the Analysis of the text of the second line).

BO SE future "will be" (see the same item in the Analysis of the text of the second line).

I PO conjunction "and" (in the aversive sense: instead); PO adverb: then. Potom in Russian; in Slovenian in potém; in Polish i potem; i potoa in Macedonian; in Slovak a potom án potá in nediško, and so on. It is not unlike of the po' (after, then) in Venetian dialect (eg: e varda, po', look then).

I KRIVIN(E) means "and also lying, false, deceitful". The first meaning of the Slavic etymology KRIV is "curved, crooked", but its current metaphorical meaning is "false, not right, wrong" (kriv, in Bulgarian and Macedonian, in Ser- 
bian, Bosnian and Croatian means "wrong", also "guilty": in Slovenian na kriva pota means "on the wrong path" and krivec, the culprit; in nediško, krit means to hide, cover, and kriu reo, guilty, delinquent; in Lithuanian kreivas, curved, crooked. In Paleo-Venetic KRIV with quality suffix -IN (see the entry VONIN in the Analysis of the text of the third line) means "liar, or guilty." But KRIVINE, with the final E, presents itself as the predicative case of the noun KRIVINA and could mean "with deceit, with lies, in error". From the etymology KRIV derives the name of a female character of South Slavic mythology: the krivapete, wild women, as wise as they are cruel, who live isolated by the streams. their characteristic is to have curved feet, almost overturned.

A conjunction. In some Slavic languages, "a" means "e", in the adversative sense (in Lithuanian õ) corresponding to "but", as in Russian. In other Slavic languages, it takes the form "ali, ale". It can be replaced by the conjunction " $i$ " (see above I KRIVINE).

DIA is supposed to be the first syllable of DIARITOR, the referee-judge of disputes.

The linguistic, morphological lexical analysis of the fifth line confirms the Current Translation already proposed: He made a speech [the DIARITOR, the judge?]: Maybe he prays a lot, but then he also deceives, but the DIA (...)

\subsubsection{Sixth Line of the Tavola da Este}

Hypothetical word division (based on and Figure 8 and keywords: NITA KERME MOL): S DOTIKE LUD [JAMI] NITA (...) K V KERME NOŠOL MOL [TEVE]

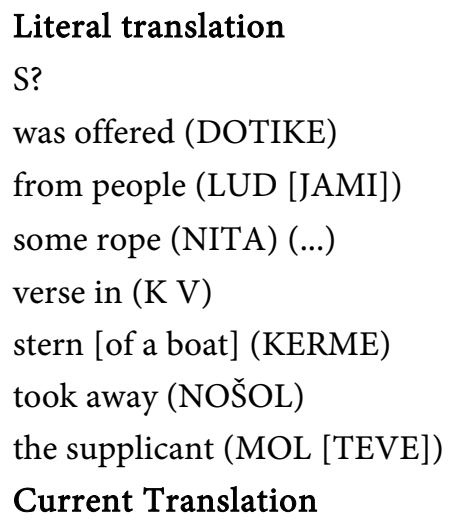

He was offered a rope by the people, to get into the stern [of the boat that] carried off the supplicant. One wonders if the "supplicant" is begging the DIARITOR to be merciful, or if he is praying to the deities who saved him from drowning.

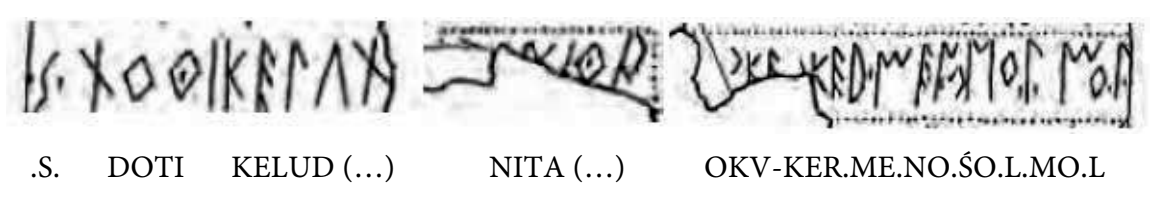

Figure 8. Sixth line of the Tavola da Este. 


\section{Text Analysis}

DOTIKE means "has been given". It is implied "him, to him". The verb DOTI (gives; see in the Analysis of the text of the first line) would appear, here, in the passive form, with a termination "KE" already encountered in other $\mathrm{Pa}$ leo-Venetic texts (eg: OSTSKE, has been stopped, i.e. he was killed), of Etruscan origin, unless it comes from the Greek suffix $\theta \eta$ (dhe) of the passive aorist time.

LUD [JAMI] means "by the people". In all Slavic languages the collective name ljudi means "persons, people, men": in Slovenian it is ljudi, as in Croatian, Serbian, Bosnian, Russian; in Slovak it is ludí; in Polish ludzie; in Macedonian luǵe (pronounced luđe). A termination in the plural instrumental case (ami) is assumed, since it is an agent's complement after the passive verb DOTIKE.

$\operatorname{NITA}(. .$.$) The term nit-nitka means "thread, string" in the Slavic vocabulary;$ nić in Sorbian, nit in Nediško. Become niška in Bulgarian and Macedonian. The Venetian term nissiòi, bed sheets (from nitiòi) seems to derive from the etymology nit and means "sheets of thread". NITA could be the genitive case of NIT, in fact, implying "a piece of", or "of" thread. In this case, more than a wire, it would be a real rope, to which the castaway can cling to get into the boat. According to the previous sequences, the castaway passes from the dock, where he was unconscious and where he was offered wine, to the boat.

$\mathrm{K} \mathrm{V}$ prepositions of motion to place: $\mathrm{K}$ means "towards, in the direction of" (see the entry K VAN, in the Analysis of the text of the fourth line). V means "inside, in the interior" (see V PATTAPLANAM in the Text Analysis of the second line).

KERMA means "stern of a boat" (in Croatian and Serbian na krme broda, in Bosnian na krmi broda, aft of the ship. The South Slavic form krma becomes kormà in Russian, karma in Belarusian, korma in Ukrainian, with addition of a vowel, as usually happens in the passage of the most ancient Slavic languages to the most recent ones. The meaning is confirmed by Ambrozič \& Tomezzoli (2003). Returning to the protagonist of the scene, it seems to intuit that the accused-castaway is recovered and saved.

NOŠOL reflecting on the Slavic verb nosit-nositi-nosić which means "to bring, to bear", conjugated in the past tense, to the 3rd person singular (in Polish niósł, Slovak niesol, Czech nesl, Croatian and Serbian nosio, Slovenian Russian nosil, brought-carried) seems to mean "[it] took him away". Marinetti (1993) transcribes NOŠON, with final "N", and not "L", but in all the reproductions available of the "Este table" we can clearly read NOŠOL.

MOL is perhaps the first syllable of the already known word MOLTEVE, in prayer (see the entry MOLTEV(E) in the Analysis of the text of the second line). It is presented as the object complement (the supplicant) of the verb NOŠOL: the boat has carried away the supplicant.

The linguistic, lexical and morphological analysis of the sixth line confirms the Current Translation already proposed: He was offered a rope by the people, to get into the stern [of the boat that] took the supplicant away. 


\section{Conclusion}

\section{Translation of the text by linking the six lines between them}

Despite the notable perimeter cuts suffered by this inscription and the gaps in the sheet that prevent the reading of some words, it is possible, by combining the translation of the individual lines, to grasp a logic in this narration, a red thread. There he is: (...) The presence of an arbitrator who examines and judges disputes disputes (diaritor svag) (...) offers (...) protection to the individual (baro) (first line, the most external). (...) Someone (Vor, a thief?) has taken away a horse (je gnos ekvo), he is barefoot and prays (bos i molteve). In order for him to be considered credible, the judge (DIARITOR) will have the accused throw (da naj) into the flooded river ( $\mathrm{v}$ pattaplanam) (second line, choosing the second hypothesis of interpretation, in which JE GNOS means "took away"). So it happens. Here he is [prey] to the waves (valgam) of a volume of several spans. A threatening (or putrid?) mass of water (los lok) has [him] wrapped up to the good part of the bank (quay) (perikon), which smells of aromas (vonin) (third line). And the meriga offered (...) wine (kenon), right in this part [of the quay], even to him now without strength (venev), more dead than alive ( $\mathrm{k}$ van), but in reality he is sleeping (varo spai) (fourth line). He made a speech (reke reč) (who? The judge?): maybe he is one who prays a lot, but then he also deceives (i po i krivine), but the DIA (...) (fifth line). He was offered (dotike) by the people (lud[ami]) a piece of rope (nita) (...), to go up to the stern ( $\mathrm{k} v$ kerme) [of a boat that took him] away ... (sixth line). A happy ending can be imagined. Evidently the protagonist of the story was a sincere repentant, or an innocent, or a "pardoned" by the divinity to which he is devoted.

The attempt to link the six lines of the text of the Tavola da Este together, despite the gaps and cuts in the sheet, can certainly lead to inconsistencies. For example, one wonders: can this semi-drowned young man climb the bank alone? Can they offer him wine while he's still in the water? Or when he is already lying on the dock, at the end of his strength? And the rope offered to him in the last sequence is used to pass from the dock to the boat, and not from the water? Everyone can answer according to their own common sense and experiences.

The analytical translation has therefore brought out a narrative text with an ethical or religious slant, which has no equal in the heritage of Paleo-Venetic writing. Is it possible that no other similar ones have been registered? Such an isolated find is strange. Not a flower blooms in the desert. Those who engraved it will surely have chiseled others as well. It is said that the Veneti worked a lot, as farmers and artisans (Polybius praises their agriculture and productivity, the general well-being in their settlements), that they devoted little time to writing. But this is stated on the basis of the finds found, and it has also become a convenient stereotype. Perhaps other inscribed texts similar to that of the Tavola da Este are still under our urban centers ... How can we explain, otherwise, that two of the greatest Latin poets (Catullus and Virgil) the most scientific mind of Latin literature (Pliny), and some of the earliest historians of Rome (Volusius, Tito Li- 
vio and Cornelio Nepote) came out of the "illiterate" Veneti? Tacitus came from Narbonne Gaul, in close relations with the Adriatic area, at the time of the Empire. Instead, a legitimate doubt arises: what if the Romans, as rulers, made to disappear the inscriptions (stories, parables, public acts) which, directly or indirectly, dealt with Veneti customs and habits? What if they had let circulate only dedicatory texts, in any case "harmless", which did not somehow obstruct the new culture of imperial Rome, with its law, its values and its administration? It goes without saying that even the barbarian hordes, in their passage, have plundered, destroyed or reused, according to their needs, goods and objects they found, including bronze plates.

This translation does not have the presumption of having definitively clarified the meaning of the tavola da Este, since many identified Baltoslav words do not have a single possible translation. In any case, it is intended to open a confrontation on it. It is a hypothesis of interpretation which, however, demonstrates, like many other Paleo-Venetic texts, the Paleo-Slavic origin of the Paleo-Venetic language. It shows, at least, that some typically Slavic terms, etymons and idioms are the key words of this text. That is to say that, especially by resorting to the Slavic languages, in addition to the contribution of Greek, it is possible to make logical and coherent translations, albeit differentiated and subject to discussion. Even the detractors of the "Slavic theory" cannot deny it. Moreover, no supporter of the affinity between Paleo-Slavic and Latin or Etruscan has yet managed to propose a single hypothesis of real, concrete understanding of this inscription. We can compare with the interpretation of Ambrozič \& Tomezzoli (2003) because there are no others and, coincidentally, it also uses Slavic lexicon and etymons.

The second confirmation that can be obtained from this translation is that the Paleo-Venetic, or Venetic, language has been substantially described by Italian historians and glottologists in the last two centuries, but all in all it has been neglected in its semantic value. Yet it is a historical-archaeological evidence of primary importance for learning about the Paleo-Venetic civilization.

What are the reasons? The main ones seem to be three:

- the first, because it was considered a poor and repetitive language, to which it does not deserve to devote too much effort; certainly not as rich as Sanskrit or the Greek language;

- the second, due to the difficulty of understanding it, which makes give up the endeavour. Moreover, the few who monopolize this field of study, perched on their positions, have never accepted new proposals from other backgrounds, such as, for example, Anton Škerbinc's idea of the Slovenes indigenous in the Alpine region. Or that of Favero (2016) that "Veneti" are the continuing peoples of the civilization of Lusatia in the context of the Civilization of the Urn Fields (in L'alba dei Veneti);

- the third, due to an upstream cultural conditioning, of national-fascist origin, according to which all civilization had sprung from Rome, caput mundi. Yet 
the Danubian "Old European culture", as Marija Gimbutas called it, precedes the birth of Rome by millennia ${ }^{6}$. For fascism it was not even admissible that a part of the Italians were of Slavic origin: the Slavic lands had to be conquered and their populations degraded, canceled, starting with the language, italianizing their toponyms and even their family names! To realize the degree of provincialism reached, it would be enough to read the medieval Chronicles, such as that of San Colombano: "Veneti qui et Sclavi dicuntur" (the Veneti who are also called Slavs). The lack of interdisciplinarity has complicated the things. Archaeologists are not interested in languages, linguists are not concerned with protohistory, therefore archaeologists and linguists do not collaborate with each other, they work "in watertight compartments". But the solution to this problem lies precisely in interdisciplinarity, a fundamental tool now in all disciplines, not only in historical and linguistic studies. Thanks to an interdisciplinary research, the Tavola da Este perhaps would not have remained lying, misunderstood, for so many years!

\section{Familiarity between Paleo-Venetic and Slavic languages}

The homogeneity between the various languages belonging to the Slavic family, despite the enormous extension of the area in which they are spoken (Alinei, 2000), has always struck language historians, Vostokov, cited by Alinei (2000), observed the lack of differences between the various languages. The Slavic languages up to the 9th century! It is thanks to this homogeneity, both in the etymology and in the morphology, that it is quite easy to recognize a term belonging to the Slavophony. The same consideration of homogeneity can be made for the Paleo-Venetic language with respect to the Paleo-Slavic languages. The Paleo-Venetic has been supplanted by Latin, so much so that the Paleo-Venetic vocabulary has almost completely disappeared from the current Venetian-Friulian dialects, which mostly consist of venetianized Latin terms. The loss of the autonomy of the Italic peoples, including the Veneti, with respect to the Roman Empire, also meant the loss of their language. On the other hand, the Paleo-Slavic languages have been preserved almost intact, apart from neologisms linked to fashions and technologies, even in regions conquered by the Roman Empire.

The similarity, in some cases even the coincidence, between many $\mathrm{Pa}$ leo-Venetic expressions and the corresponding Slavic expressions of the past and even today is surprising. Therefore it seemed useful to us to propose a small glossary that compares the lexicon of the Tavola da Este with the corresponding Russian words (be they nouns, verbs, adjectives, prepositions, etc.). The Illyrian and Danubian Slavic languages are the most ancient, therefore the most related to the Paleo-Venetic, and also the closest to the North-East of Italy. It is not surprising that they resemble Paleo-Venetic, while Russian is the youngest language of the Slavic family and the farthest from the Alpine-Adriatic region. Yet it has

${ }^{6}$ Born in the lower Danube basin (Serbia, Romania, Bulgaria), this civilization counts Lepensky Vir, Vinča, Tărtăria, Varna among its main sites. The Vinča script (or Tablets of Tărtăria (Tomezzoli \& Serafimov, 2008), in Transylvania), the first worldwide evidence of alphabetic writing, developed between the 6 th and 3 rd millennium BC. 
many words similar, or even identical, to the Paleo-Venetic ones, since in the Russian sedimented the characteristics of the language that the Slavophones-Venedi-Wenden-Winidi brought with them, migrating to north-eastern Europe, beyond the swamps of the river Pripyat', in the early Middle Ages. Russian words tend to be richer in vowels and a little longer than the Paleo-Slav ones (for example: Russian derevo, lumber, is drvo in Croatian, Serbian, Bosnian; Russian roditeli, parents, is rodzice in Polish, rodiče in Czech; Russian dorogòj, dear, is drago in Slovenian, drag in Serbian).

Glossary of paleo-Venetic terms (source: Tavola da Este) commonly used in Russian

(the terms are transliterated into the Latin alphabet. The grave accent indicates the tonic accent)

Paleo-Venetic

$\mathrm{A}$

BARA-O

BOS

DATI

$\mathrm{DE}$

DIE

DOUKAI

EKVO

GNOS

I

$\mathrm{PO}$

KRIV

KRMA

KUD

LOS

LOK

LUDI

MERA

MNOIO

MOLTEVA

NITA

NOŚOTI

$\mathrm{ON}$

PATTAPLANA

PED

PERIK

PROIVOS

REŚ

SPAI

\section{Russian}

a (conjunction " $\mathrm{e}$ " in the adverse sense: but)

oboròna (defense, protection, pronunciation abaròna)

bosòj (barefoot)

dat'-davàt' (give)

že (in fact, just)

užè (now)

do togo (until); dolgo kak (until when?)

kon' (horse)

gnòj (pus, repulsive thing)

i (conjunction “and")

potòm (adverb "then”)

krivòj (curved, crooked, false)

kormà (stern, rear)

kudà (adverb "where"; in Russian movement to place)

zlòj (bad)

lug (wet ground, lawn)

ljùdi (people, persons)

mèra (measure)

mnògo (adverb “very”)

molitva (prayer)

nit'-nitka (thread)

nosit' (to bring)

on (he)

potoplènie (sinking, shipwreck, pronunciation

pataplènie)

pjad' (span)

bèreg (shore, bank, pronunciation bèrik))

pràvyj (right, correct, good)

reč' (word, language, speech)

spi (sleeps) 


$\begin{array}{ll}\text { SPATI } & \text { spat' (to sleep) } \\ \text { TAI } & \text { (this) tak (like this) } \\ \text { TO (U) OM } & \text { tovàrom (with a load) } \\ \text { U-V } & \text { v (preposition "in") } \\ \text { VALG } & \text { val (wave) } \\ \text { VENEV } & \text { vjànutyj (withered, without strength) } \\ \text { VERA } & \text { vèra (faith) } \\ \text { VERO } & \text { vèrno (actually, according to justice) } \\ \text { VITI } & \text { vìt'sja (wrap around, whirl) } \\ \text { VON } & \text { von (smell) (in Russian, bad smell). }\end{array}$

Treviso, 18 September 2021

Gina Pigozzo Bernardi

\section{Acknowledgements}

English translation of the article by G. Tomezzoli.

\section{Conflicts of Interest}

The author declares no conflicts of interests regarding the publication of this paper.

\section{References}

AA.VV. (2001-2002). AKEO. The Times of Writing (Exhibition, Museum of Montebelluna, 2001-2002, Cornuda, 2002).

AA.VV. (2013a). Este. Guide of the National Museum. Regional Directorate of Museums of the Veneto and Ministry of Culture.

AA.VV. (2013b). VENETKENS (Exhibition, Padua 2013). Marsilio.

Alinei, M. (2000). Origins of the Languages of Europe (2 Vols.). Il Mulino.

Ambrozič, A., \& Tomezzoli, G. (2003). The “Tavola da Este” Inscription. In Proceedings or the International Workshop: Traces of European Past (pp. 132-146). Založništvo Jutro. http://www.korenine.si/zborniki/zbornik03/ambr tomez este.html

Bor, M., Šavli, J., \& Tomažič, I. (1991). The Veneti Ancestors of European Man. Ed. VENETI.

Boutet, M.-G. (2021). The Inscriptions of the Danube Civilization Decoded. Academia.edu.

Cordenons, F. (1894). A Little More Light on the Origins of the Euganei-Veneti. Tipografia del Seminario.

Favero, P. (2016). L'Alba dei Veneti. Mito e Storia delle Origini. Cierre Grafica.

Lejeune, M. (1974). Manuel de la langue vénète. UniversitätsVerlag.

Marinetti, A. (1993). La tavola venetica iscritta da Este. Appunti preliminari. Terra d'Este No. 3/1993 (See Also AKEO, 2001-2002).

Pääbo, A. (2011). A Description of the Pre-Roman ${ }^{\star}$ Era. Apsley.

https://parnodesmentegar.files.wordpress.com/2012/03/venetic-language.pdf

Pauli, C. (1891). Altitalische Forschungen. Barth.

Pigozzo Bernardi, G. (2020). At the Origins of the Veneti Civilization. From the Ancient Language to the Venetian-Friulian Dialects. Piazza Editore. 
Pigozzo Bernardi, G. (2021). La stele del monte Pore. Slavia, n. 3/2021.

Preobraženskij, A. G. (1959). Russian Etymological Dictionary. Gosudarstvennoe Izdatel'stvo ... slovarej, Moskva.

Rubini, E. (2010). Giustizia veneta. Filippi Ed.

Tomezzoli, G., \& Serafimov, P. (2008). The Inscriptions of Tartaria. In Skvortsov (Ed.), Pre Cyrillic Slavic Script and Pre-Christian Slavic Culture, Materials of the First International Congress (Vol. 2).

Vodopivec, V. (1941). Jezikovni Temelji Starejše Slovenske Etnogeneze. https://www.korenine.si/knige/jezik temelji slov etnogeneze.pdf 